\title{
Evaluation of genetic diversity and traits relations in wheat cultivars under drought stress using advanced statistical methods
}

\author{
Mohammad Reza NAGHAVI $^{1^{*}}$, Marouf KHALILI ${ }^{2}$
}

Received February 17, 2017; accepted May 08, 2017.

Delo je prispelo 17. februarja 2017, sprejeto 08. maja 2017.

\begin{abstract}
In order to study of genetic diversity and classify physioagronomic characters under normal irrigation and drought stress in wheat cultivars, 15 cultivars were evaluated in the research farm of University of Mahabad, Iran. According to stepwise regression some of traits entered to final model that as far to correlation coefficients and path analysis regarding, the biggest part of correlation coefficient and direct effect was achieved for number of grains per spike, number spikes per plant with grain yield under two conditions. These traits had the highest indirect effect on the grain yield mutually. So, screening for high value for these traits can bring increase in wheat grain yield under two conditions. Factor analysis detected three and four factors which explained 91.23 and 92.43 percent of the total variation in non-drought stress and drought stress conditions, respectively. In drought stress condition the first factor, second factor, third factor and fourth factors were named as yield component, physiological, biomass and growth, and yield factor respectively. Cluster analysis based on the three and four factors grouped cultivars into the two groups under normal and three groups under drought stress conditions. Generally, tolerant cultivars can be used for direct culture or as parents for create of variation in breeding programs.
\end{abstract}

Key words: correlation; drought stress; factor analysis; path analysis; physio-agronomic traits; wheat
IZVLEČEK

\author{
OVREDNOTENJE GENETSKE RAZNOLIKOSTI IN \\ RAZMERIJ MED LASTNOSTMI PRI SORTAH \\ KRUŠNE PŠENICE V RAZMERAH SUŠNEGA STRESA \\ S STATISTIČNIMI METODAMI
}

$\mathrm{Z}$ namenom preučevanja genetske raznolikosti in razvrščanja fizioloških in agronomskih lastnosti je bilo $v$ razmerah sušnega stresa in normalnega namakanja ovrednotenih 15 sort krušne pšenice na raziskovalnem polju University of Mahabad, Iran. S postopno regresijo so nekatere lastnosti vključili v končni model na osnovi koeficientov korelacije in standardiziranih koeficientov multiple regresije in ugotovili, da so imele največji neposredni učinek $\mathrm{v}$ obeh razmerah poskusa lastnosti kot so število zrn na klas, število klasov na rastlino in pridelek zrnja. Te lastnosti so imele hkrati tudi največji neposrednik učinek na pridelek zrnja. Iskanje sort z velimi vrednostmi teh lastnosti lahko poveča pridelek pšenice $\mathrm{v}$ obeh razmerah poskusa. Faktorska analiza je ugotovila tri, oziroma štiri faktorje, s katerimi lahko razložimo 91.23 in 92.43 odstotkov celukupne variabilnosti v razmerah brez suše in ob sušnem stresu. V razmerah sušnega stresa so prvi, drugi, tretji in četrti faktor poimenovani kot komponento pridelka, fiziološki parametri, biomasa in rast ter pridelek. Klasterska analiza je na osnovi treh in štirih faktorjev uvrstila sorte $v$ dve skupini $\mathrm{v}$ normalnih razmerah in $\mathrm{v}$ tri skupine $\mathrm{v}$ razmerah sušnega stresa. V splošnem bi odporne sorte lahko gojili neposredno $\mathrm{v}$ prozvodnji ali jih uporabili kot starše pri ustvarjanju raznolikosti v žlahtniteljskih programih.

Ključne besede: korelacija; sušni stres; faktorska analiza, multipla regresija; fiziološko-agronomske lastnosti; krušna pšenica

\section{INTRODUCTION}

Common wheat (Triticum aestivum L.) as the most important cereal crop is cultivated throughout the major agro-climatic zones of the world (Baik and Ullrich,
2008). World's wheat production was about 735.23 million tons in 2016 (FAO, 2016). Drought stress is the most important factor limiting crops production in

1 Assistant Professor, Department of Agriculture, Payame Noor University, PO BOX 19395-3697 Tehran, Iran; *Corresponding author: mr_naghavi@ymail.com

2 Assistant Professor, Department of Agriculture, Payame Noor University, PO BOX 19395-3697 Tehran, Iran 
agricultural systems in arid and semi-arid regions (Mollasadeghi et al., 2011). Drought stress is recognized as an important factor that affects the wheat growth and yield (Ashraf, 1998). Some morphological traits such as number of spike per $\mathrm{m}^{2}$, number of grains per spike, number of fertile tillers per plant, 1000-grain mass, peduncle length, spike mass, stem mass and grain yield affect wheat tolerance to the moisture shortage in the soil (Plaut et al., 2004; Blum, 2005). Grain yield is a complex multi component character and is greatly influenced by various environmental conditions. Various morphological and physiological characters contribute to grain yield (Kahrizi et al., 2010). Also, environmental conditions and genotype interaction affect the relationships among plant characters. So, toward a clear understanding of the type of plant traits, correlation and path coefficient analysis are logical steps (Kashif and Khaliq, 2004). Path analysis is a tool that is available to the breeder for better understanding the cause involved in the associations between traits and to partition the existing correlation in to direct and indirect effects, through a main variables (Lorencetti et al., 2006). Generally, this method provides more information among variables than do correlation coefficients since this analysis provides the direct effects of specific yield components on yield, and indirect effects via other yield components (Garcia del Moral et al., 2003). Path analysis has been widely used in crop breeding to determine the nature of relationships between grain yield and its contributing components, and to identify those components with significant effect on yield for potential use as selection criteria (Board et al., 1997; Khalili et al., 2013; Naghavi et al., 2014). Different statistical techniques have been used in modeling crops yield, including correlation, regression, path analysis, factor analysis, factor components and cluster analysis (Mohamed, 1999). Factor analysis suggested by Walton (1972) has been widely used to identify growth and plant characters related to wheat (Moghaddam et al., 1998; Naghavi et al., 2015). This method basically reduces a large number of correlated variables to a small number of uncorrelated variables or factors. This method is a strong method that has been used to estimate the components of yield, to extract a subset of identical variables, to identify the basic concepts of multivariable data, to recognize applied and biological connections among the traits, to reduce a large number of correlative traits to a few number of factors and to explain the correlation among the variables (Bramel et al., 1984). Cluster analysis can be used to identify variables which can be classified into main groups and subgroups based on similarity and dissimilarity. This technique is useful for parental selection in breeding programs (El-Deeb and Mohamed, 1999) and crop modeling (Jaynes et al., 2003). Naghavi et al. (2015) showed a negative correlation between plant height and grain yield. They attributed that to the lower number of grains/spike with the tallest wheat plants. Kumbhar et al. (1983) and Mohamed (1999) had shown that grain mass/spike, biological yield and number of spikes $/ \mathrm{m}^{2}$ were closely related to grain yield $\mathrm{g} / \mathrm{m}^{2}$. The differential relations of yield components to grain yield may be attributed to environmental effects on plant growth (Asseng et al., 2002). Khayatnezhad et al. (2010) using factor analysis in his studies on durum wheat cultivars showed that the importance of factor coefficients characteristics of total and fertile tillers, main spike length, 1000-seed mass, and yield selected genotypes is desirable for dry conditions. Also, Naghavi, et al., (2015) used the factor analysis to identify growth and morphological traits relevant to yield in wheat and introduced four factors which included yield components, morphological traits, spike length and the number of grain per plant.

Our objective was to determine the relationship between grain yield and related characters under normal irrigation and drought stress. Also, one of another goals in this study was founding the direct and indirect effects of morphological and agronomic traits on grain yield under two conditions. On the other hands, the another objectives of this investigation were evaluate the relations of different characters and also identifying effective factors in yield improvement in wheat cultivars and grouping of cultivars according to achieved factors under normal irrigation and drought stress.

\section{MATERIALS AND METHODS}

Fifteen cultivars of wheat such as Mahabad Landrace cultivar and Sardari, Zarin, Azar, Homa, Alamoot, Shahriyar, Mihan, Zare, Urum, Pishgam, Toos, Alvand, Navid, Sabalan were cultivated in a split plot basis of randomized complete block design with four replications under two different conditions (normal irrigation and no irrigation after booting stage) at Research Farm of University of Mahabad, Iran (latitude $36.46^{\circ} \mathrm{N}$, longitude $45.43^{\circ} \mathrm{E}$, Altitude $1385 \mathrm{~m}$ above sea level) during growing season of 2015-2016. The climate is characterized by mean annual precipitation of 330 $\mathrm{mm}$; mean annual temperature of $12^{\circ} \mathrm{C}$. The experimental treatments consisted of irrigation levels as the main plot at second levels: irrigation after $70 \mathrm{~mm}$ evaporation from class A pan (without stress), irrigation after $150 \mathrm{~mm}$ evaporation from class A pan (water deficit stress) and fifteen cultivars of wheat as the sub plot were considered in this study. Each plot contained 4 
rows with $25 \mathrm{~cm}$ apart and $1 \mathrm{~m}$ in length. All plots were irrigated after sowing and subsequent irrigations in the beginning of stem elongation. Weeds were controlled by hand during crop growth and development.

Agronomic characteristics and physiological criteria including: plant height $(\mathrm{cm})$, plant dry mass $(\mathrm{g})$, specific leaf area $\left(\mathrm{cm}^{2} / \mathrm{g}\right)$, relative water content $(\%)$, proline content, chlorophyll content (ChC) and osmotic potential (OP), spike length $(\mathrm{cm})$, number of tillers per plant, number of fertile tillers per plant, number of spikes per plant, number of grains per spike, 1000grains mass $(\mathrm{g})$, grain yield $(\mathrm{g})$, were measured after the physiological maturity in 10 selected plants of each experimental plot, randomly.

Physiological criteria were used for flag leaf measurement. Specific leaf area was calculated on the basis of this formula: special leaf area $\left(\mathrm{cm}^{2} \mathrm{~g}^{-1}\right)=$ (leaf area)/(leaf dry mass) (Arias, 2007). Moreover, relative water content $(\%)$ was determined according to method of Turner (1986). Also, proline contents (mg.g $\mathrm{g}^{-1} \mathrm{FM}$ ) were measured by acid hydrin method. The chlorophyll content was determined using a chlorophyll meter
(SPAD-502, Japan). Osmotic potential was measured by osmometer (Martinez et al. 2004); mode: Osmomat 010, Genotel. Morphological and growth traits such as the plant height $(\mathrm{cm})$, plant dry mass $(\mathrm{g})$, spike length $(\mathrm{cm})$, number of tillers per plant, number of fertile tillers per plant, number of spikes per plant, number of grain in spike, 1000 grain mass (g) and grain yield (g) were measured at the end of growth stage. Finally, mean of data used for analysis and simple linear correlation coefficients were computed and these coefficients were subjected to path analysis as described by Dewey and Lu (1959) using SPSS software. Also, mean of data used for analysis and simple linear correlation coefficients were computed then factor analysis on the base of major factors analysis and varimax rotations was done on the data. The factors which had a root bigger than one were selected and were used to form factorial coefficients matrix (Sharma, 1985; Tadesse and Bekele, 2001). Also eigen values, percent variance, variance, and cumulative percentage share of each of the extracted factors were calculated. Finally cluster analysis was performed according to values for cultivars basis of factors. Analysis of data and drawing of dendrogram were performed with SPSS software.

\section{RESULTS AND DISCUSSION}

\subsection{Analysis of variance}

The results of analysis of variance (Table 1) showed high significant differences $(\mathrm{P}<0.01)$ between of cultivars for all traits, except SLA and OP which was significant in probability level $\mathrm{P}<0.05$. Also difference between normal irrigation and drought stress was significant for all of traits. This indicates that the magnitude of differences in cultivars was sufficient to select them against drought. Also, results indicated that there is a high variation for all traits which revealed the presence of genetic diversity for these attributes in the materials. Therefore, these traits have good potential for selection of the most tolerant and most sensitive cultivars for using in cross together and create genetically variation or using of direct culture for tolerant cultivars.

At the study of Garavandi and Kahrizi (2010), in which 20 bread wheat genotypes were evaluated, grain yield, spike number per square meter, number of seed per spike, spike density and awn length had the heights genetic diversity in compare with other traits. Kutlu and Kinaci, (2010) reported similar results for agromorphological traits and grain yield in both stress and non-stress conditions. Also, Farshadfar (2012) showed significant difference among wheat genotypes in term of physiological traits under stress and non-stress. 
Table 1: Analysis of variance for yield and other traits in wheat cultivars under different irrigation treatment

\begin{tabular}{ccccccccc}
\hline $\begin{array}{l}\text { Source of } \\
\text { Variation }\end{array}$ & df & \multicolumn{7}{c}{ Mean of Squares } \\
\cline { 3 - 9 } & & $\dagger$ PH & PDM & SLA & RWC & PC & ChC & OP \\
\hline $\begin{array}{c}\text { Replication } \\
\text { (R) }\end{array}$ & 3 & 0.956 & 0.004 & 35.906 & 0.430 & 0.163 & 0.298 & 0.055 \\
Stress (S) & 1 & $421.98^{* *}$ & $236.982^{* *}$ & $702.76^{* *}$ & $45.83^{* *}$ & $3.739^{* *}$ & $19.837^{* *}$ & $0.629^{* *}$ \\
Error a & 3 & 0.409 & 0.008 & 246.317 & 0.003 & 0.104 & 0.049 & 0.053 \\
Genotype & 14 & $98.764^{* *}$ & $5.278^{* *}$ & $184.91^{* *}$ & $69.724^{* *}$ & $3.089^{* *}$ & $13.656^{* *}$ & $0.873^{* *}$ \\
$(\mathrm{G})$ & 14 & 24.891 & 1.073 & $310.189^{*}$ & 11.897 & $1.932^{*}$ & 0.985 & $5.167 * *$ \\
$\mathrm{G} \times \mathrm{S}$ & 84 & 30.670 & 1.853 & 118.872 & 13.096 & 0.458 & 1.005 & 0.198 \\
Error b & & 11.58 & 8.46 & 11.76 & 9.98 & 12.09 & 11.65 & 13.96 \\
\hline CV $(\%)$ & & & & & & & & \\
\hline
\end{tabular}

$\dagger \mathrm{PH}, \mathrm{PDM}, \mathrm{SLA}, \mathrm{RWC}, \mathrm{PC}, \mathrm{ChI}$ and OP indicate plant height, plant dry mass, specific leaf area, relative water content, proline content, chlorophyll content and osmotic potential respectively. Also, * and ** were significant at $5 \%$ and $1 \%$ probability levels.

Table 1: continued

\begin{tabular}{|c|c|c|c|c|c|c|c|c|}
\hline \multirow{2}{*}{$\begin{array}{l}\text { Source of } \\
\text { Variation }\end{array}$} & \multirow{2}{*}{ df } & \multicolumn{7}{|c|}{ Mean of Squares } \\
\hline & & $\dagger \mathrm{SpL}$ & NT & NFT & NSp & NGSp & 1000-GM & GY \\
\hline $\begin{array}{l}\text { Replication } \\
\text { (R) }\end{array}$ & 3 & 0.061 & 0.550 & 0.499 & 0.329 & $43.871 *$ & 23.987 & 0.873 \\
\hline Stress (S) & 1 & $353.894 * *$ & $451.159 * *$ & $490.461 * *$ & $543.134 * *$ & $556.092 * *$ & $3984.930 * *$ & $2196.561 * *$ \\
\hline Error a & 3 & 0.054 & 2.129 & 1.128 & 2.094 & 18.186 & 28.44 & 4.457 \\
\hline $\begin{array}{c}\text { Genotype } \\
\text { (G) }\end{array}$ & 14 & $11.873 * *$ & $15.905 * *$ & $16.047 * *$ & $18.947 * *$ & $110.857 * *$ & $65.192 * *$ & $18.903 * *$ \\
\hline $\mathrm{G} \times \mathrm{S}$ & 14 & 0.436 & 1.198 & 1.209 & 1.762 & 11.940 & 8.093 & 2.320 \\
\hline Error b & 84 & 0.936 & 1.122 & 1.432 & 1.875 & 12.945 & 9.670 & 2.406 \\
\hline $\mathrm{CV}(\%)$ & & 10.55 & 13.08 & 17.49 & 18.21 & 13.44 & 10.55 & 18.98 \\
\hline
\end{tabular}

$\dagger$ SpL, NT, NFT, NSp, NGSp, 1000-GM and GY indicate spike length, number of tillers per plant, number of fertile tillers, number of spikes per plant, number of grains per spike, 1000 grain mass and grain yield respectively. Also, * and ** were significant at $5 \%$ and $1 \%$ probability levels.

\subsection{Correlation analysis}

According to the results of the correlation, significant positive correlation was found between grain yield and spike length, number of tillers per plant, number of fertile tillers, under both conditions (Table 2). Moreover of these traits plant dry mass, relative water content, proline content, chlorophyll content, number of spikes per plant and number of grains per spike had significant positive correlation with grain yield under drought stress (Table 2). Also, significant negative correlation was found between grain yield and plant height, specific leaf area and osmotic potential under drought stress condition (Table 2).

Maximum of amount of correlation coefficients between studied traits with grain yield was achieved for number of grains per plant and number of spikes per plant under normal irrigation and drought stress. On the other hands, a negative significant correlation was found between 1000 -seed mass and number of grains per spike under two irrigation conditions. Plant height was positively correlated with plant dry mass under both conditions. Also, correlation analysis showed physiological traits values were positive significantly correlated together under two conditions. Further, number of tillers with number of fertile tillers and number of spikes per plant had significant positive correlation under normal irrigation and drought stress. Also, spike length showed positive and significant correlation with number of grains per spike under normal irrigation and drought stress. 
The analysis of correlation of different traits with grain yield can help to make decision about the relative importance of these traits and their merits as selection criteria (Dokuyucu and Akkaya, 1999). Various studies show that grain yield of wheat is significantly correlated with 1000-grain mass, the number of fertile tillers or spikes per plant and the number of spikelets per spike (Mohiuddin and Cory, 1980; Shanahan et al., 1985). Moghaddam et al. (1998) reported that yield, 1000-grain mass, and number of spikes per plant were correlated. In most of the previous studies, similar have been reported between yield and related characters such as, number of spikes, number of spikelets and 1000-grain mass (Sharma and Rao, 1989; Subhani and Khaliq, 1994). In the studies conducted by Sinha and Sharma (1979) and Belay et al. (1993), yield was positively correlated with yield components, with either positive or negative correlation between yield and plant height. Moghaddam et al. (1997) reported negative correlation between number of grains per spike and 1000-grain mass. Further, Passioura (1997) and Leilah and Al-Khateeb (2005) reported that grain yield of wheat has a positive correlation with number of spikes $/ \mathrm{m}^{2}, 1000$-grain mass, harvest index and biomass. Also, Fatemi Rika et al. (2013) reported significant correlation among grain yield, fertile tillers number, thousand grain mass, straw yield, plant biomass and harvest index under two conditions. Some of researches showed positive significant correlation between grain yield and number of spikes per plant (Kahrizi et al., 2010, Naghavi et al. 2015).

Table 2: Coefficient correlation between studied traits with grain yield under normal irrigation (under main diagonal) and under drought stress (above main diagonal)

\begin{tabular}{|c|c|c|c|c|c|c|c|c|c|c|c|c|c|c|}
\hline & $\uparrow \mathrm{PH}$ & PDM & SLA & RWC & $\mathrm{PC}$ & $\mathrm{ChC}$ & $\mathrm{OP}$ & SpL & NT & NFT & NSp & NGSp & $\begin{array}{c}1000- \\
\text { GM }\end{array}$ & GY \\
\hline $\mathrm{PH}$ & 1 & $0.96^{* *}$ & 0.40 & -0.33 & -0.34 & -0.40 & -0.41 & 0.32 & -0.39 & 0.36 & 0.23 & 0.43 & -0.41 & $-0.51 *$ \\
\hline PDM & $0.90^{* *}$ & 1 & $-0.52 *$ & 0.32 & $0.60 * *$ & $0.69^{* *}$ & -0.29 & -0.28 & 0.39 & 0.32 & 0.24 & $0.77 * *$ & $-0.67 * *$ & $0.60^{* *}$ \\
\hline SLA & 0.37 & -0.28 & 1 & -0.17 & -0.40 & -0.41 & 0.40 & -0.40 & 0.30 & 0.20 & 0.37 & $-0.68 * *$ & $0.60 * *$ & $-0.73 * *$ \\
\hline RWC & -0.11 & 0.29 & -0.09 & 1 & $0.66 * *$ & $0.60^{* *}$ & -0.30 & $0.79 * *$ & $0.80^{* * *}$ & $0.82^{* *}$ & $0.84 * *$ & 0.32 & $0.53^{*}$ & $0.94 * *$ \\
\hline PC & -0.20 & 0.26 & -0.20 & $.58 * *$ & 1 & $0.75^{* *}$ & $-0.61 * *$ & $0.76^{* * *}$ & $0.61^{\text {*** }}$ & $0.76^{* *}$ & $0.61 * *$ & -0.23 & 0.31 & $0.84 * *$ \\
\hline $\mathrm{ChC}$ & -0.19 & 0.28 & -0.28 & 0.38 & $0.65^{* *}$ & 1 & $-0.63^{* *} *$ & $0.67 * *$ & $0.76^{* * *}$ & $0.90^{* *}$ & $0.74 * *$ & $-0.80 * *$ & $0.83^{* *}$ & $0.71^{* *}$ \\
\hline OP & -0.23 & -0.08 & 0.26 & -0.37 & $-0.64 * *$ & -0.40 & 1 & $-0.53 *$ & -0.30 & -0.43 & $-0.61 * *$ & -0.32 & 0.41 & $-0.65^{* *}$ \\
\hline $\mathrm{SpL}$ & 0.25 & -0.10 & -0.19 & $0.60^{* *}$ & $0.66^{* * *}$ & 0.39 & -0.33 & 1 & $0.76^{* * *}$ & $0.77^{* *}$ & $0.87 * *$ & $0.88 * *$ & $0.75^{* *}$ & $0.73^{* *}$ \\
\hline NT & -0.20 & 0.15 & 0.32 & $0.63^{* *}$ & $0.63 * *$ & 0.36 & -0.35 & $0.64 * *$ & 1 & $0.88^{* *}$ & $0.80^{* *}$ & $-0.60 * *$ & 0.60 ** & $0.79^{* *}$ \\
\hline NFT & 0.28 & 0.12 & 0.29 & $0.61^{* *}$ & $0.59 * *$ & 0.31 & -0.23 & $0.60 * *$ & $0.60^{* *}$ & 1 & $0.84^{* *}$ & $-0.54 *$ & $0.65^{* *}$ & $0.95^{* *}$ \\
\hline NSp & 0.10 & 0.08 & 0.28 & $0.62 * *$ & 0.42 & 0.35 & -0.31 & $0.60 * *$ & 0.61 ** & $0.63^{* *}$ & 1 & $0.52 *$ & $0.69 * *$ & $0.93 * *$ \\
\hline NGSp & 0.40 & 0.21 & -0.40 & -0.40 & -0.30 & -0.19 & -0.23 & $0.53^{*}$ & -0.28 & -0.26 & -0.22 & 1 & $-0.69 * *$ & $0.98 * *$ \\
\hline $\begin{array}{c}1000- \\
\text { GM }\end{array}$ & -0.39 & -0.30 & 0.38 & 0.23 & 0.28 & 0.44 & 0.27 & $0.53 *$ & 0.30 & 0.25 & 0.29 & $-0.52 *$ & 1 & -0.19 \\
\hline GY & -0.30 & -0.12 & -0.16 & 0.31 & 0.36 & 0.48 & -0.11 & 0.59 ** & 0.74 ** & $0.54 *$ & 0.42 & 0.41 & -0.21 & 1 \\
\hline
\end{tabular}

$\dagger$ PH, PDM, SLA, RWC, PC, ChC, OP, SpL, NT, NFT, NSp, NGSp, 1000-GM and GY indicate plant height, plant dry mass, specific leaf area, relative water content, proline content, chlorophyll content, osmotic potential, spike length, number of tillers per plant, number fertile tillers, number of spikes per plant, number of grains per spike, 1000 grain mass and grain yield respectively. Also, ${ }^{*}$ and $* *$ were significant at $5 \%$ and $1 \%$ probability levels.

\subsection{Path analysis}

Path analysis was used to describe correlation to identify direct and indirect effects for entered traits into regression model. Path coefficient analysis was conducted by considering yield-related traits as predictor variables and grain yield as the response variable. In the control condition, comparing the direct and indirect effects between grain yield and some related traits were calculated (Table 3, 4). In this state, grain yield was positively correlated with chlorophyll content, number spikes per plant, number of grains per spike and negative correlation with 1000 grain mass and amount of correlation coefficient for 1000 grain mass was less rather than other traits (Table 4). According to this results and as regards to amounts of direct effects traits under normal irrigation the best of traits for selection of plant with high grain yield were chlorophyll content, number spikes per plant and number of grains per spike, because these traits had high direct effect and high correlation coefficient with grain yield under normal irrigation (Table 3, 4).
On the other hands, under drought stress condition, number of grains per spike, relative water content, number of spikes per plant, proline content and 1000 grain mass were entered to final regression model (Table 3). All of these traits showed a positive significant correlation with grain yield except of 1000 grain mass (Table 5). Under drought stress, traits such as number of grains per spike, number of spikes per plant and relative water content showed average direct effect on grain yield and these results showed that these traits act via other traits, cumulative effects with high positive correlations on grain yield was expressed. On the other hands, 1000 grain mass showed good direct effect on grain yield under drought stress but their effect via indirect effect of other traits decreased their correlation with grain yield (Table 5). The biggest part of correlation and direct effect on grain yield under drought stress was achieved for number of grains per spike, proline content and number of spikes per plant. 
Generally, number of grains per spike and number of spikes per plant were the best criterion for improving grain yield in wheat under normal irrigation and drought stress conditions. So, screening for high amount for these traits can bring increase in wheat grain yield under two conditions. Naghavi et al., (2014), using path analysis in wheat found that the number of spikes per plant and number of fertile tillers had significant positive, direct effects on grain yield under drought stress conditions, as well as well-watered conditions. On the other hands, Baranwal et al., (2012) revealed that number of grains per spike, spike length and 1000-grain mass exhibited the maximum positive direct effect on grain yield. Also, Sheron et al., (1986) observed that yield components such as number of grains per spike and number of spikes per plant with plant height and spike length were directly related to grain yield.

Table 3: Results of stepwise regression analysis for grain yield as the response to other characters as predictors in non-stress and water deficit stress conditions

\begin{tabular}{|c|c|c|c|c|c|c|c|}
\hline \multirow{2}{*}{$\begin{array}{c}\text { Stress } \\
\text { conditions }\end{array}$} & \multirow{2}{*}{ Model } & \multirow{2}{*}{$\mathrm{t}$-values } & \multicolumn{2}{|c|}{$\begin{array}{l}\text { Unstandardized } \\
\text { Coefficients }\end{array}$} & \multirow{2}{*}{$\begin{array}{c}\text { Standardized } \\
\text { Coefficients } \\
\beta\end{array}$} & \multirow{2}{*}{$\mathrm{R}^{2}$} & \multirow{2}{*}{$\begin{array}{c}\text { Adjusted } \\
\mathrm{R}^{2}\end{array}$} \\
\hline & & & $\beta$ & Std. E. & & & \\
\hline \multirow{5}{*}{ 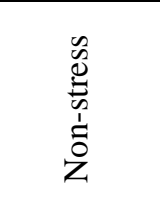 } & Constant $(\alpha)$ & -0.955 & -4.343 & 0.855 & & \multirow{5}{*}{0.598} & \multirow{5}{*}{0.583} \\
\hline & Number of Grains per Spike & 0.112 & 0.064 & 0.009 & 0.434 & & \\
\hline & Chlorophyll Content & 0.094 & 0.070 & 0.008 & 0.576 & & \\
\hline & 1000 Grain Mass & -0.112 & -0.062 & 0.012 & -0.367 & & \\
\hline & Number of Spikes per plant & 0.128 & 0.063 & 0.012 & 0.432 & & \\
\hline \multirow{6}{*}{ 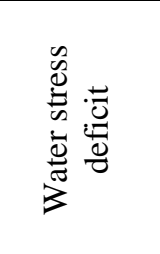 } & Constant $(\alpha)$ & -0.124 & -1.932 & 0.543 & & \multirow{6}{*}{0.634} & \multirow{6}{*}{0.622} \\
\hline & Number of Spikes per plant & 0.118 & 0.063 & 0.014 & 0.387 & & \\
\hline & Number of Grains per Spike & 0.099 & 0.065 & 0.006 & 0.437 & & \\
\hline & 1000 Grain Mass & -0.139 & -0.073 & 0.013 & -0.543 & & \\
\hline & Relative water content & 0.102 & 0.061 & 0.014 & 0.365 & & \\
\hline & Proline Content & 0.125 & 0.074 & 0.003 & 0.643 & & \\
\hline
\end{tabular}

$\dagger$ NGSp, ChC, 1000GM and NSp indicate number of grains per spike, chlorophyll content, 1000 grain mass and number of spikes per plant, respectively. Also, values in main diagonal are direct effects.

Table 4: Path analysis of grain yield with related traits in cultivars of wheat under irrigation conditions

\begin{tabular}{cccccc}
\multirow{2}{*}{$\begin{array}{c}\text { variables added to the } \\
\text { model }\end{array}$} & $\dagger$ NGSp & ChC & 1000GM & NSp & $\begin{array}{c}\text { Correlation } \\
\text { coefficient with } \\
\text { grain yield }\end{array}$ \\
\cline { 2 - 6 } NGSp & $\mathbf{0 . 4 3 4}$ & -0.111 & 0.189 & -0.096 & 0.412 \\
ChC & -0.083 & $\mathbf{0 . 5 7 6}$ & -0.162 & 0.149 & 0.477 \\
1000GW & -0.224 & 0.254 & $\mathbf{- 0 . 3 6 7}$ & 0.124 & -0.210 \\
NSp & -0.097 & 0.199 & -0.105 & $\mathbf{0 . 4 3 2}$ & 0.423
\end{tabular}

$\dagger$ NGSp, ChC, 1000GM and NSp indicate number of grains per spike, chlorophyll content, 1000 grain mass and number of spikes per plant, respectively. Also, values in main diagonal are direct effects. 
Table 5: Path analysis of grain yield with related traits in cultivars of wheat under drought stress

\begin{tabular}{ccccccc}
\hline \multirow{2}{*}{$\begin{array}{c}\text { variables added } \\
\text { to the model }\end{array}$} & $\dagger$ NSp & NGSp & $1000-G M$ & RWC & PC & $\begin{array}{c}\text { Correlation coefficient } \\
\text { with grain yield }\end{array}$ \\
\cline { 2 - 7 } & $\mathbf{0 . 3 8 7}$ & 0.229 & -0.373 & 0.307 & 0.393 & 0.931 \\
NSp & 0.202 & $\mathbf{0 . 4 3 7}$ & 0.374 & 0.118 & - & 0.149 \\
NGSp & & & & & 0.978 \\
1000-GM & 0.266 & -0.301 & $\mathbf{- 0 . 5 4 3}$ & 0.195 & 0.201 & -0.193 \\
RWC & 0.326 & 0.141 & -0.290 & $\mathbf{0 . 3 6 5}$ & 0.421 & 0.942 \\
PC & 0.237 & -0.101 & -0.169 & 0.239 & $\mathbf{0 . 6 4 3}$ & 0.840
\end{tabular}

$\dagger \mathrm{NSp}, \mathrm{NGSp}, 1000$-GM, RWC and PC indicate number of spikes per plant, number of grains per spike, 1000 grain mass, relative water content and proline content, respectively. Also, values in main diagonal are direct effects.

\subsection{Factor analysis}

Since coefficients of correlation may singly not provide thorough information about the relations of different traits and given the various advantages of multivariate statistical analyses for deep understanding of data structure, factor analysis was used in the current study. By means of varimax rotation which maximizes the variance among the factors, the factors which justify more percentage of variations among the characters have had more importance and must be studied. So, the effective characters on each factor are identified and the factors are named according to the most effective characters (Tadesse and Bekele, 2001). In factor analysis by means of major factors analysis and on base of specific numbers larger than 1 , under normal and stress conditions three factors were identified under normal irrigation and four factors were identified under drought stress and they all together justify 91.23 and 92.43 percent of existent variation among the characters, respectively (Table 6 and 7).

Under normal condition the first factor which made $50.43 \%$ of the total variation was composed of the spike length, number of tillers per plant, number of fertile tillers per plant, number of spikes per plant, number of grains per spike, 1000 grain mass and grain yield. So, first factor was named as grain yield and yield components factor. Factor 2, which accounted $25.67 \%$ of the total variation, was composed of plant height and plant dry mass and thus this factor was called as biomass factor. Factor 3, which accounted $15.13 \%$ of the total variation, included specific leaf area, relative water content, proline content, chlorophyll content and osmotic potential. Because these traits were related to physiology so, this factor was named as physiological factor. On the other hand, under drought stress condition the first factor justified $36.23 \%$ of total variation which included number of spikes per plant, number of grains per spike, 1000 grain mass. Therefore, this factor was identified as yield components factor. The second factor was composed of specific leaf area, relative water content, proline content, chlorophyll content and osmotic potential explained $24.18 \%$ of total variation. Thus this factor was called as physiological factor. Factor 3, which accounted $18.26 \%$ of the total variation, included plant height and plant dry mass. So, this factor was named as biomass factor. Factor 4, which accounted $13.76 \%$ of the total variation was composed of spike length, number of tillers per plant, number of fertile tillers per plant and grain yield and thus this factor was called as growth and grain yield factor. These results showed that cultivars with the highest values of these factors had the highest values for associated traits to those factors. In general, factor analysis showed which from the factors under normal and drought stress condition, yield components factor with description of high amount from total variation was common that it showed importance of related traits to it.

Naghavi et al. (2015) used factor analysis to reduce variables in wheat cultivars and they reported four factors (growth and grain yield, grain traits, biomass and root) and two factors (grain yield and biomass) under normal and drought stress, respectively. Khayatnezhad et al. (2010) on durum wheat cultivars showed that the importance of factor coefficients characteristics of growth traits (fertile tillers and main spike length), 1000 -seed mass and yield selected genotypes is desirable under drought stress. Also, Gholamin et al. (2010) showed the importance of factor coefficients related to biomass and yield components for selection of desirable genotypes under dry conditions. In other studies on bread wheat cultivars, Dawari and Luthra (1991) revealed that number of grains per spike, spike length and harvest index were the main yield components and that the selection in terms of them could improve the yield. 
Table 6: Factor analysis for agro-morphological traits in wheat cultivars under normal irrigation

\begin{tabular}{|c|c|c|c|c|}
\hline Traits & 1 & 2 & 3 & Communalities \\
\hline$\dagger \mathrm{PH}$ & -0.159 & 0.608 & -0.015 & 0.877 \\
\hline PDM & 0.395 & 0.642 & 0.204 & 0.901 \\
\hline SLA & -0.412 & -0.003 & 0.508 & 0.887 \\
\hline RWC & 0.305 & 0.199 & 0.621 & 0.931 \\
\hline $\mathrm{PC}$ & 0.278 & 0.251 & 0.748 & 0.922 \\
\hline $\mathrm{ChC}$ & 0.290 & 0.198 & 0.814 & 0.909 \\
\hline $\mathrm{OP}$ & -0.343 & -0.078 & 0.567 & 0.912 \\
\hline $\mathrm{SpL}$ & 0.902 & 0.204 & 0.312 & 0.941 \\
\hline NT & 0.936 & 0.229 & 0.235 & 0.949 \\
\hline NFT & 0.909 & 0.301 & 0.109 & 0.907 \\
\hline $\mathrm{NSp}$ & 0.907 & 0.278 & 0.205 & 0.919 \\
\hline NGSp & 0.831 & 0.290 & -0.346 & 0.859 \\
\hline 1000-GM & 0.649 & 0.389 & 0.223 & 0.894 \\
\hline GY & 0.908 & 0.335 & 0.309 & 0.885 \\
\hline Eigen values & 9.71 & 4.98 & 2.33 & \\
\hline Proportional variance & 50.43 & 25.67 & 15.13 & \\
\hline Cumulative variance & 50.43 & 76.10 & 91.23 & \\
\hline \multicolumn{5}{|c|}{$\begin{array}{c}\dagger \text { PH, PDM, SLA, RWC, PC, ChC, OP, SpL, NT, NFT, NSp, NGSp, 1000-GM and GY } \\
\text { indicate plant height, plant dry mass, specific leaf area, relative water content, proline } \\
\text { content, chlorophyll content, osmotic potential, spike length, number of tillers per plant, } \\
\text { number of fertile tillers, number of spikes per plant, number of grains per spike, } 1000 \text { grain } \\
\text { mass and grain yield respectively. }\end{array}$} \\
\hline
\end{tabular}

Table 7: Factor analysis for agro-morphological traits in wheat cultivars under drought stress

\begin{tabular}{cccccc}
\hline Traits & 1 & 2 & 3 & 4 & Communalities \\
\hline$\dagger$ PH & -0.034 & -0.173 & 0.798 & 0.309 & 0.893 \\
PDM & 0.128 & 0.109 & 0.856 & 0.356 & 0.904 \\
SLA & -0.325 & 0.656 & -0.105 & -0.267 & 0.899 \\
RWC & 0.304 & 0.890 & 0.187 & 0.197 & 0.889 \\
PC & 0.250 & 0.776 & 0.298 & 0.258 & 0.910 \\
ChC & 0.318 & 0.809 & 0.167 & 0.102 & 0.875 \\
OP & -0.201 & 0.656 & 0.095 & -0.219 & 0.876 \\
SpL & 0.373 & 0.232 & 0.184 & 0.687 & 0.924 \\
NT & 0.315 & 0.207 & 0.390 & 0.898 & 0.897 \\
NFT & 0.309 & 0.203 & 0.167 & 0.783 & 0.901 \\
NSp & 0.898 & 0.307 & 0.249 & 0.401 & 0.899 \\
NGSp & 0.786 & 0.150 & 0.193 & 0.308 & 0.932 \\
1000-GM & 0.843 & 0.209 & 0.295 & 0.411 & 0.902 \\
GY & 0.256 & 0.247 & 0.145 & 0.913 & 0.882 \\
\hline Eigen values & 4.53 & 4.13 & 2.46 & 2.02 & \\
Proportional & 36.23 & 24.18 & 18.26 & 13.76 & \\
variance & & & & & \\
Cumulative & 36.23 & 60.41 & 78.67 & 92.43 & \\
variance & & & & \\
\hline
\end{tabular}

$\dagger$ PH, PDM, SLA, RWC, PC, ChC, OP, SpL, NT, NFT, NSp, NGSp, 1000-GM and GY indicate plant height, plant dry mass, specific leaf area, relative water content, proline content, chlorophyll content, osmotic potential, spike length, number of tillers per plant, number of fertile tillers, number of spikes per plant, number of grains per spike, 1000 grain mass and grain yield respectively. 


\subsection{Cluster analysis based on extracted factors}

According to the importance of all the studied traits and regarding to the correlation among traits that was effective in different factors, cultivars grouped on the basis of all factors under normal irrigation (Figure 1) and drought stress (Figure 2). According to the impact of factor coefficients cultivars were grouped according to tolerance and sensitivity under drought stress (Table 8 and 9). Cluster analysis with cutting of discriminant analysis based on the three and four factors under two conditions, cultivars grouped into the two and three groups under normal irrigation and drought stress respectively (Figure 1 and 2).

Under normal irrigation, 9 cultivars such as Urum, Sabalan, Zarin, Sardari, Alvand, Azar, Homa, Pishgam and Mahabad landrace were classified in the first cluster, forming group1. Cultivars in this cluster are linked with the highest rate to first to third factors (Table 8, Figure 1). So, these cultivars have high values for physiological traits, biomass traits and grain yield and yield components. Second group comprises 6 cultivars such as Toos, Mihan, Alamoot, Navid,
Shahriyar and Zare. Cultivars of this cluster showed the lowest values for first to third factor. So, these cultivars have the lowest values for grain yield and yield components and other traits (Table 8).

On the other hands, under drought stress in the first group were placed 6 cultivars such as Pishgam, Toos, Alamoot, Homa, Mahabad landrace and Mihan. These cultivars showed average values of all factors and so cultivars of this group were named semi tolerant (semisensitive) (Table 9, Figure 2). Also, the second group was comprised of 3 cultivars such as Navid, Zare and Shahriyar which showed the lowest values for factor 1 to 4 , so these cultivars had the lowest values of physiological traits, biomass, yield components and grain yield (Table 9). Further, third group included Sabalan, Urum, Azar, Sardari, Zarin and Alvand cultivars with the highest values for all of the traits according to factor 1 to 4 (Table 9). Generally cluster 3 and 2 were the most tolerant and the most sensitive cultivars under drought stress (Figure 2). So, cultivars of these clusters with inter-cross can be used to increase grain yield in breeding programs.

Table 8: The average of traits for achieved groups from cluster analysis based on factor analysis in 15 wheat cultivars under normal irrigation

\begin{tabular}{cccc}
\hline Clusters & Factor 1 & Factor 2 & Factor 3 \\
\hline 1 & 125.549 & 126.749 & 129.729 \\
2 & 113.738 & 108.396 & 118.639 \\
\hline
\end{tabular}

Table 9: The average of traits for achieved groups from cluster analysis based on factor analysis in 15 wheat cultivars under drought stress

\begin{tabular}{ccccc}
\hline Clusters & Factor 1 & Factor 2 & Factor 3 & Factor 4 \\
\hline 1 & 45.745 & 47.498 & 9.094 & 42.375 \\
2 & 38.709 & 42.439 & 5.984 & 37.630 \\
3 & 48.230 & 56.264 & 13.395 & 44.629 \\
\hline
\end{tabular}




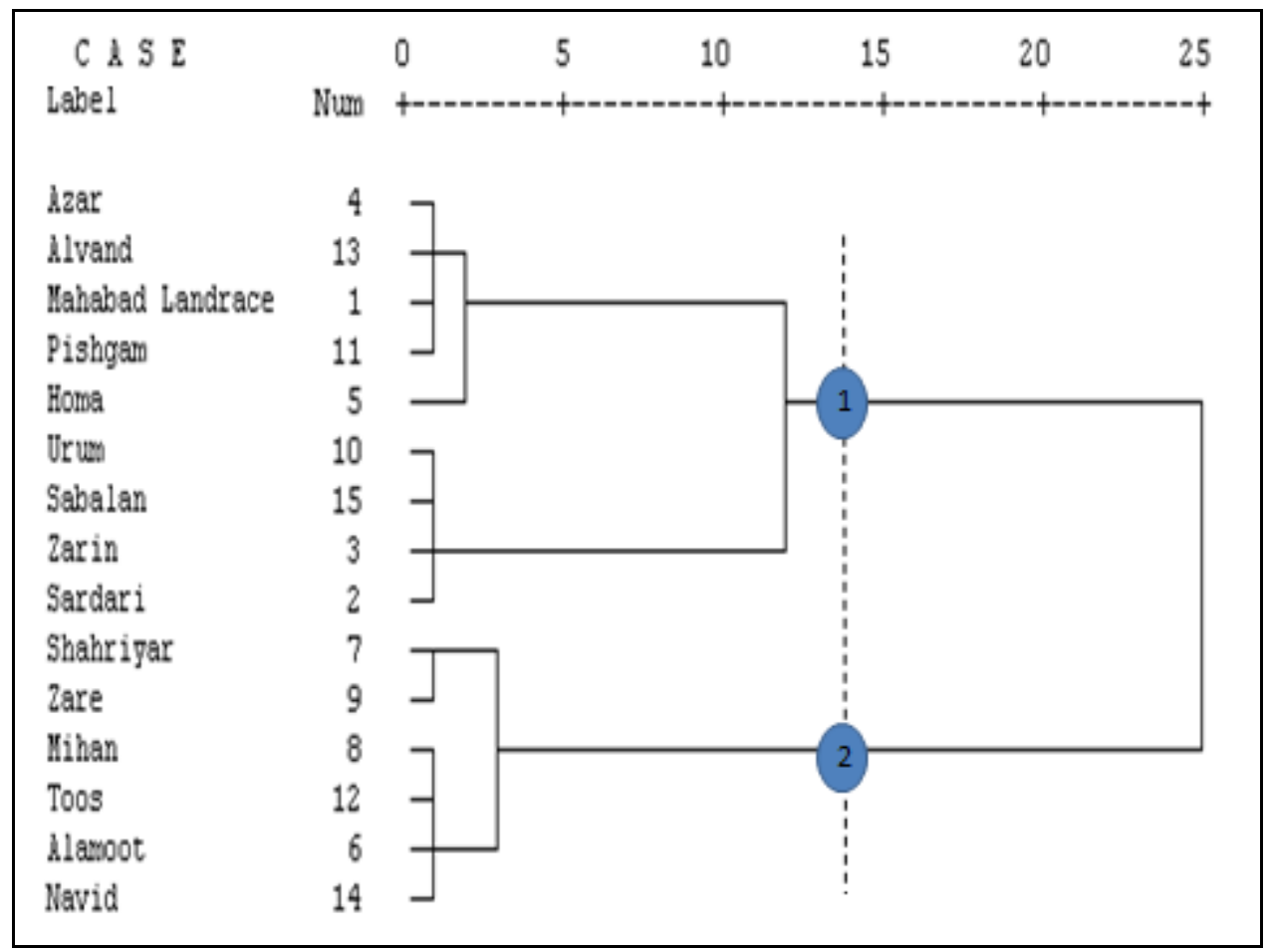

Figure1: Dendrogram for factors coefficient and cutting of discriminant analysis under normal irrigation

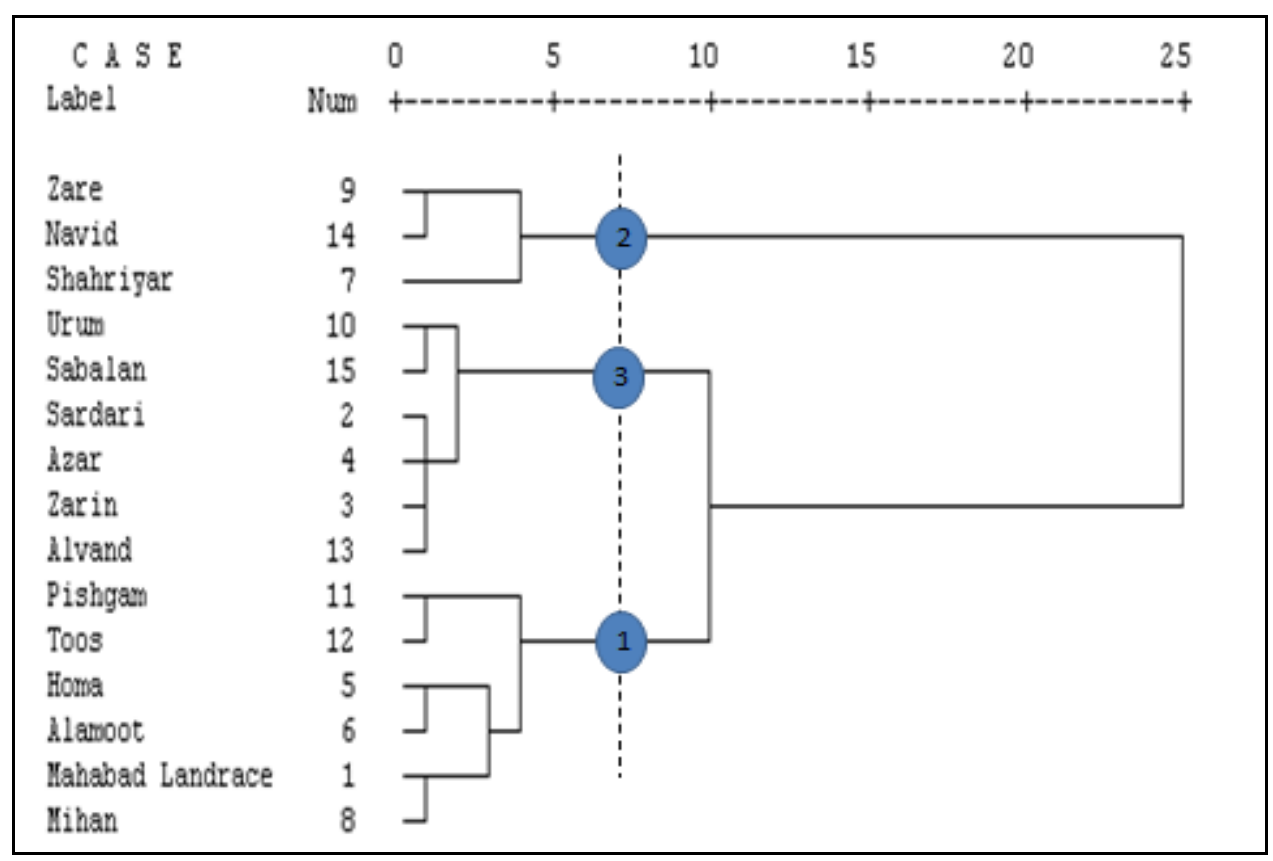

Figure 2: Dendrogram for factors coefficient and cutting of discriminant analysis under drought stress 


\section{CONCLUSIONS}

Considering to our results, number of grains per spike and number of spikes per plant were the best criterion for improving grain yield in wheat under normal irrigation and drought stress conditions. So, screening for high values of these traits can bring increase in wheat grain yield under two conditions. Factor analysis detected three and four factors which explained 91.23 and 92.43 percent of the total variation in non-drought stress and drought stress conditions, respectively. In normal condition the first, second and third factor were identified as yield and yield components, biomass and physiological factors, respectively. While, under drought stress condition the first factor, second, third and fourth factors were named as yield components, physiological, biomass factor, growth and yield factor. Generally by cluster analysis with factors values was known "Sabalan, Urum, Azar, Sardari, Zarin, Alvand "and "Navid, Zare, Shahriyar" cultivars as the most tolerant and sensitive cultivars, respectively. Also, for further selection and breeding, parents may be selected from those clusters which had significant genetic distance for crossing in order to obtain genetic recombination and transgressed segregation in the subsequent generations. Also, it is suggested that in arid and semi-arid regions tolerant cultivars used directly.

\section{ACKNOWLEDGMENTS}

The costs for this experiment were ensured by the first authors' research grant and the authors are grateful to the research section of Payame Noor University under the Ministry of Science, Research and Technology of
Iran. Also they express their gratitude to cereal department of grain improvement and breeding institute of Karaj, Iran for preparing the grains of wheat cultivars used in the experiments.

\section{REFERENCES}

Ashraf, M. Y. (1998). Yield and yield component response of wheat (Trittium aestivum L.) genotypes grown under different soil water deficit conditions. Acta Agronomica Hungarica, 46, 45-51.

Asseng, S., Turnera, N. C., Rayb, J. D., Keatingc, B. A. (2002). A simulation analysis that predicts the influence of physiological traits on the potential yield of wheat. European Journal of Agronomy, 17(2), 123141. doi:10.1016/S1161-0301(01)00149-6

Baik, B. K., Ulrich, E. (2008). Barley for food: Characteristics, improvement and renewed interest. Journal of Cereal Science, 48(2), 233-242. doi:10.1016/j.jcs.2008.02.002

Baranwal, D. K., Mishra, V. K., Vishwakarma, M. K., Yadav, P. S., Arun, B. (2012). Studies on genetic variability, correlation and path analysis for yield and yield contributing traits in wheat (T. aestivum L. em Thell.). Plant Archives, 12(1), 99-104.

Belay, G., Tesemma, T., Becker, H. C., Merker, A. (1993). Variation and interrelationships of agronomic traits in Ethiopian tetraploid wheat landraces. Euphytica, 71, 181-188. doi:10.1007/BF00040407

Blum, A. (2005). Mitigation of drought stress by crop management.

http://www.plantstress.com/articles/drought _m7drought_m.htm.

Board, J. E., Kang, M.S., Harville, B. G. (1997). Path analyses identify indirect selection criteria for yield of late-planted soybean. Crop Science, 37, 879-884. doi:10.2135/cropsci1997.0011183X003700030030x

Bramel, P. J., Hinnz, P. N., Green, D. E., Shibles, R. M. (1984). Use of principal factor analysis in the study of three stem termination types of soybean. Euphytica, 33, 387- 400. doi:10.1007/BF00021136

Damania, A. B., Jackson, M. T. (1986). An application of factor analysis to morphological data of wheat and barley landraces from the Bheri River Valley, Nepal. Rachis, 5, 25-30.

Dawari, N. H., Luthra, O. P. (1991). Character association studies under high and low environments in wheat (Triticum aestivum L.). Indian Journal of Agricultural Research, 25, 515-518.

Delmer, D. P. (2005). Agriculture in the developing world: connecting innovations in plant research to downstream applications. Proceedings of the National Academy of Sciences USA, 102, 15739-15746. doi:10.1073/pnas.0505895102

Dewey, D. R., Lu, K. H. (1959). Correlation and pathcoefficient analysis of components of crested wheat grass seed production. Agronomy Journal, 51, 515518. doi:10.2134/agronj1959.00021962005100090002x

Dokuyucu, T., Akkaya, A. (1999). Path coefficient analysis and correlation of grain yield and yield components of wheat (Triticum aestivum L.) genotypes. RACHIS Newsletter, 18, 17-20. 
El-Deeb, A. A., Mohamed N. A. (1999). Factor and cluster analysis for some quantitative characters in sesame (Sesamum indicum L.). The Annual Conference ISSR, Cairo University, 4-6 December,Vol. 34, Part (II).

Farshadfar, E. (2012). Application of integrated selection index and rank sum for screening drought tolerant genotypes in bread wheat, IJACS, 4(6), 325-332.

Fatemi Rika, Z., Paknejhad, F., Amiri, E., Eilkaee, M. N., Mirtaheri, S. M. (2013). Investigation of traits correlations and path analysis of barley (Hordeum vulgare L.) seed yield under terminal drought-stress conditions. International Journal of Biosciences, 3(11), 115-121.

Food and Agriculture Organization (2016). Statistics: FAOSTAT agriculture. from http://fao.org/crop/statistics.

Garavandi, M., Kahrizi, D. (2010). Evaluation of genetic diversity of bread wheat genotypes for phenologic and morphologic traits. The $11^{\text {th }}$ Crop Science and Plant Breeding Congress Iran, pp: 537-541.

Garcia del Moral, L. F., Rharrabti, Y., Villegas, D., Royo, C. (2003). Evaluation of grain yield and its components in durum wheat under Mediterranean conditions: an ontogenic approach. Agronomy Journal, 95, 266-274. doi:10.2134/agronj2003.0266

Gholamin, R., Zaeifizadeh, M., Khayatnezhad, M. (2010). Factor analysis for performance and other characteristics in durum wheat under drought stress and without stress. Middle East Journal of Scientific Research, 6(6), 599-603.

Golparvar, A. R., Ghannadha, M. R., Zhalli, A. A., Ahmadi, A. (2002). Evaluation of some morphological traits as selection criteria for improvement of bread wheat. Iranian Journal of Agricultural Science, 4(3), 202-207. (In Persian)

Harman, H. H. (1976). Modern Factor Analysis. 3rt Ed. University of Chicago Press, Chicago. pp: 376.

Jaynes, D. B., Kaspar, T. C., Colvin, T. S., James, D. E. (2003). Cluster analysis of spatio temporal corn yield pattern in an Iowa field. Agronomy Journal, 95(3), 574-586. doi:10.2134/agronj2003.0574

Kahrizi, D., Maniee, M., Mohamadi, R., Cheghamirza, K. (2010). Estimation of genetic parameters related to morpho-agronomic traits of Durum Wheat (Triticum turgidum var. durum). Biharean Biologist, 4(2), 93-97.

Kang, M. S., Miller, J. D., Tai, P. Y. P. (1983). Genetic and phenotypic path analyses and heritability in sugarcane. Crop Science, 23, 643-647. doi:10.2135/cropsci1983.0011183X002300040010x

Kashif, M., Khaliq, I. (2004). Heritability, correlation and path analysis for some metric traits in wheat. International Journal of Agricultural Biology, 6, 138142.
Khalili, M., Pour Aboughadareh, A. R., Naghavi, M. R., Naseri Rad, H. (2013). Path analysis of the relationships between seed yield and some of morphological traits in safflower (Carthamus tinctorius L.) under normal irrigated and rainfed conditions. Technical Journal of Engineering Applied Science, 3(15), 1692-1696.

Khayatnezhad, M., Zaefizadeh, M., Gholamin, R., Jamaati Somarin, S., Zabihi Mahmoodabad, R. (2010). Study of morphological traits of wheat cultivars through factor analysis. American-Eurasian Journal of Agriculture and Environmental Science, 9(5), 460464.

Kutlu, I., Kinaci, G. (2010). Evaluation of drought resistance indicates for yield and its components in three Triticale Cultivars. Journal of Tekirdag Agricultural Faculty, 7(2), 95-103.

Kumbhar, M. B., Larik, A. S., Hafiz, H. M., Rind, M. J. (1983). Interrelationship of polygenic traits affecting grain yield in Triticum aestivum L.. Wheat Information Services, 57, 42-45.

Leilah, A., Al-Khateeb, S. A. (2005). Statistical analysis of wheat yield under drought conditions. Journal of Arid Environmental, 61, 483-496. doi:10.1016/j.jaridenv.2004.10.011

Lorencetti, C., de Carvalho, F. I. F., de Oliveira, A. C., Valério, I. P., Hartwig, I., Benin, G., Schmidt, D. A. M. (2006). Applicability of phenotypic and canonic correlations and path coefficients in the selection of oat genotypes. Science of Agriculture (Piracicaba Brazillian), 63, 11-19. doi:10.1590/S010390162006000100003

Martinez, J. P., Lutls, S., Schanck, A., Bajji, M. (2004). Is osmotic adjustment required for water stress resistance in the Mediterranean shrub Atriplex halmius L.? Plant Physiology, 161, 1041-1051. doi:10.1016/j.jplph.2003.12.009

Milligan, S. B., Gravois, K. A., Bischoff, K. P., Martin, F. A. (1990). Crop effects on genetic relationships among sugarcane traits. Crop Science, 30, 927-931. doi:10.2135/cropsci1990.0011183X003000040034x

Moghaddam, M., Ehdaie, B., Waines, J. G. (1997). Genetic variation and interrelationships of agronomic characters in landraces of bread wheat from southeastern Iran. Euphytica, 95, 361-369. doi:10.1023/A:1003045616631

Moghaddam, M., Ehdaie, B., Waines, J. G. (1998). Genetic variation for and inter-relationships among agronomic traits in landraces of bread wheat from southwestern Iran. Journal of Genetics and Breeding, 52(1), 73-81.

Mohamed, N. A. (1999). Some statistical procedures for evaluation of the relative contribution for yield components in wheat. Zagazig Journal of Agricultural Research, 26(2), 281-290. 
Evaluation of genetic diversity and traits relations in wheat cultivars under drought stress using advanced statistical methods

Mohammadi, M., Ghannadha, M. R., Tale'ee, A. R. (2002). Study of the genetic variation within Iranian local bread wheat lines using multivariate techniques. Seed and Plant Improvement Journal, 18(3), 328-347. (In Persian).

Mohiuddin, S. H., Cory, L. I. (1980). Flag leaf and peduncle area duration in relation to winter wheat grain yield. Agronomy Journal, 72, 299-301. doi:10.2134/agronj1980.00021962007200020011x

Mollasadeghi, V., Valizadeh, M., Shahryariand, R. A., Imani, A. (2011). Evaluation of end drought tolerance of 12 wheat genotypes by stress in dices. MEJSR, $7(2), 241-247$

Moustafa, M. A., Boersma, L., Kronstad, W. E. (1996). Response of four spring wheat cultivars to drought stress. Crop Science, 36, 982-986. doi:10.2135/cropsci1996.0011183X003600040027x

Naghavi, M. R., Moghaddam, M., Toorchi, M., Shakiba, M. R. (2014). Evaluation of the relationship between morphological and agronomic traits with grain yield in spring wheat cultivars under drought stress. International Journal of Biosciences, 5(3), 88-93. doi:10.12692/ijb/5.3.88-93

Naghavi, M. R., Toorchi, M., Moghaddam, M., Shakiba, M. R. (2015). Evaluation of diversity and traits correlation in spring wheat cultivars under drought stress. Notulae Scientia Biologicae, 7(3), 349-354. doi:10.15835/nsb.7.3.9592

Passioura, J. B. (1997). Grain yield, harvest index and water use of wheat. Journal of Australian Institute Agricultural Science, 43, 117-120.

Plaut, Z., Butow, B. J., Blumenthal, C. S., Wrigley, C. W. (2004). Transport of dry matter into developing wheat kernels. Field Crops Research, 86, 185-198. doi:10.1016/j.fcr.2003.08.005

Rajala, A., Hakala, K., Makela, P., Muurinen, S., PeltonenSainio, P. (2009). Spring wheat response to timing of water deficit through sink and grain filling capacity. Field Crop Research, 114, 263-271. doi:10.1016/j.fcr.2009.08.007

Shams-ud-din, A. K. M. (1987). Path analysis in bread wheat. Indian Journal of Agricultural Sciences, 1(3), $237-240$

Shanahan, J. F., Donnelly, K. J., Smith, D. H., Sminka, D E. (1985). Shoot developmental properties associated with grain yield in winter wheat. Crop Science, 25,
770-775.

doi:10.2135/cropsci1985.0011183X0025000500011x

Sharma, S. K. (1985). Factor analysis of berry and its seed characteristics in potato. Plant Genetics and Breeding, $37,77-82$.

Sharma, S. C. Rao, S. R. G. (1989). Genetic variability, association among metric traits and path coefficient analysis in Triticale. Annual Agricultural Research, 10(2), 145-152.

Sheron Z. S., Lauthra O. P., Kuhad M. S. (1986). Association of physiological and biochemical character with the yield of rainfed fead. Plant Breeding, 56, 5427.

Simane, B., Struik, P. C., Nachit, M. M., Peacock, J. (1993). Ontogenetic analysis of yield components and yield stability of durum wheat in water-limited environments. Euphytica, 71, 211-219. doi:10.1007/BF00040410

Sinha, G. C. P., Sharma, N. N. (1979). Correlation regression and path analysis studies in wheat varieties. Indian Journal of Agronomy, 25, 225-229.

Subhani, G. M., Khaliq, I. (1994). Path coefficient analysis in wheat. Pakistan Journal of Science Industrial Research, 37(11), 474-476.

Tadesse, W., Bekele, E. (2001). Factor analysis of yield in grass pea (Lathyrus sativus L.). Lathyrus Lathyrism Newsletter, 2, 416-421.

Talebi, R., Fayaz, F., Mohammadi Naji, A. (2009). Effective selection criteria for assessing drought stress tolerance in durum wheat (Triticum durum Desf.). General and Applied Plant Physiology, 35(1-2), 6474.

Walton, P. D. (1971). The use of factor analysis in determining characters for yield selection in wheat. Euphytica, 20, 416-421. doi:10.1007/BF00035667

Walton, P. D. (1972). Factor analysis of yield in spring wheat (Triticum aestivum L.). Crop Science, 12, 731733. doi:10.2135/cropsci1972.0011183X001200060003x

Zakizadeh, M., Esmaeilzadeh, M., Kahrizi, D. (2010). Study on genetic variation and relationship between plant characteristics and yield in long spike bread wheat (Triticum aestivum L.) genotypes using multivariate analysis. Iranian Journal of Crop Science, 12 (2), 18-30. 